\title{
Bilateral Trade Flows in the Gulf Cooperation Council Countries : What happend to the Middle East Integration after 2003?
}

\author{
Aysu Insel \\ Marmara University \\ Mahmut Tekce \\ Marmara University
}

\begin{abstract}
It is well known that the GCC countries are heavily dependent on oil and hydrocarbon industries, but during the 2003-2008 period, economic diversification is proceeded; enhancing the role of the private sector, encouraging FDI, and laying the ground for competitive integration in the globalization process. The year 2003 is special for the economic integration within the GCC due to the introduction of the custom union and high growth. This paper analzes the trade flows of the GCC countries before and after the signature of the Custom Union agreement in 2003. Fixed effects panel models have been estimated using the LS and GMM methods. It has been found that the year 2003 is special for the GCC countries. The year 2003 indicates the turning points in the intra-GCC trade and also in the GCC trade with the rest of the world. The results show that the 2003 Custom Union agreement has not fostered the intra-GCC trade, except for the United Arab Emirates, and also that the order of top fifteen trade partners has changed significantly from the EU countries and the US to the Asian countries after 2003. Additionally, the exports and imports of the GCC countries are related to the wealth of partner countries, but not distance. These results have important

\footnotetext{
*Corresponding address: Aysu Insel; Marmara University, FEAS Department of Economics (Ingilizce Iktisat Bolumu) Anadoluhisari Campus, 34810, Beykoz Istanbul, Turkey, Tel: +90 216 3082226/1142, Fax: +90 216 3082859, E-mail: ainsel@marmara.edu.tr / Mahmut Tekce; Marmara University, FEAS Department of Economics (Ingilizce Iktisat Bolumu) Anadoluhisari Campus, 34810, Beykoz Istanbul, Turkey, Tel: +90 216 3082226/1126, Fax: +90 216 3082859, E-mail: mtekce@marmara.edu.tr (C2011-Center for Economic Integration, Sejong Institution, Sejong University, All Rights Reserved.
} 
implications for the economic, cultural and political issues in trade negotiations to provide any trade incentive for the GCC countries.

- JEL Classification: C01, C33, F14, 053

- Keywords: Gulf Cooperation Council Countries, Trade Flows, Gravity Model, Panel Analysis

\section{Introduction}

In 1981, six countries of the Persian Gulf; Bahrain, Kuwait, Oman, Qatar, Saudi Arabia and the United Arab Emirates formed the Gulf Cooperation Council (GCC) and signed an economic agreement aiming at implementing a free trade region, strengthening the bargaining power with external trading partners, harmonizing development plans and adopting a common oil policy, coordinating industrial policies and linking transportation networks. ${ }^{1}$ Economic integration within the GCC has been reinforced by the introduction of the Customs Union in $2003^{2}$ and the Common Market in 2008. In addition, they agreed to introduce a single GCC currency $^{3}$ and become a monetary union by $2010 .{ }^{4}$

GCC countries have experienced a high growth rate since 2003. The GCC was the17th largest economy in 2003, and became the 13th largest economy in the world in 2008. The economies of the GCC countries heavily depend on oil income, where hydrocarbon industries represent more than $80 \%$ of total government revenues, and the share of hydrocarbons in the GDP of GCC countries is about $50 \% .{ }^{5}$ However, in the recent years, GCC countries started to diversify their economies and gave emphasis on manufacturing, finance, transportation, education and tourism sectors. As a result of this economic diversification, non-oil sector had a higher contribution to economic growth than the oil sector during the 2003-2008

\footnotetext{
${ }^{1}$ http://www.worldtradelaw.net/fta/agreements/gccfta.pdf.

${ }^{2}$ The GCC customs union have aimed to eliminate all tariff and non-tariff barriers among the member countries and set the common external tariffs at three levels; $5 \%$ tariff rate applies to most products, some agricultural and medical products have zero tariffs, and a number of restricted or protected products have selected higher tariff rates. However, the full implementation of the agreement have not yet realized.

${ }^{3}$ With the exception of Oman, that dropped out of monetary union plans in 2006.

${ }^{4}$ Recently, the deadline for the adoption of the common currency has been extended to a date to be determined by the monetary council.

${ }^{5}$ Mohieldin, M., "Point of View: Neighborly Investments", Finance \& Development, December 2008, 45,
} (4). 
period.

This paper analyzes the bilateral trade flows of the GCC countries and attempts to develop a new model using system equations through annual panel data from 1997 to 2007. The framework of the model in this paper departs from the common (augmented) gravity model, as it estimates the trade equation with the country effect equation simultaneously. In this sense, total trade and the country effects are the endogenous variables in the model, whereas real per capita GDP of the home and partner countries, population, distance and the EU, GCC, Asia and oil producer country dummies are the explanatory variables.

There are three contributions of this paper: (1) Examination of bilateral trade flows of each GCC country with its partners, individually, for two different sample periods. (2) Consideration of country effects produced by the fixed effects models and country ranking for the trade partners for each GCC country. (3) Development of a gravity model specification where bilateral trade flows and country effects are determined endogenously for each GCC country. This analysis provides the following outcomes: (1) Fixed effect panel models provide information on individual country effects. Country ranking approach reveals that the overall order of countries has not changed, but the order of the first fifteen partners has changed significantly from 1997-2002 to 2003-2007 period with regard to the data used for each GCC country. (2) The GCC countries have increased their trade activities and the standard of living after 2003. (3) Contrary to the common gravity equation for trade, the coefficient of the distance variable is commonly insignificant in the model, mainly due to the nature of the traded goods of the region.

This paper provides important implications for the bilateral trade connections of the GCC countries. The year 2003 is important for the GCC countries, and the wealth of partner countries is the main determinant both for the exports and imports of the GCC countries. These results mirror the improved bilateral trade partnership between the GCC countries and the Asian countries. After 2003, the US and the EU countries have lagged behind the effect of the economic enthusiasm of the Asia countries so that the order of top fifteen trade partners has changed significantly from the EU countries and the US to the Asian countries. The results suggest that the processes of economic integration, economic diversification, and national economic policies have crucial impacts on bilateral trade flows of the GCC countries.

The paper starts with an economic review of the GCC countries and evaluates the trade patterns of the member countries. The modified gravity model for the 
GCC trade, econometric methodology and estimation results are presented in the Section III. Section IV concludes the estimation results.

\section{International Trade Pattern of the GCC countries}

The GCC has a relatively small but an increasing share in world trade. As seen in Table 1, the share of the region in the world exports has reached $4.68 \%$, where it was around $2 \%$ in the late $1990 \mathrm{~s}$. The share the GCC merchandise imports in world imports has also increased in recent years.

The GCC countries are also characterized with highly open trade regimes and their dependence on exports and imports. As illustrated in Figure 1, the share of merchandise trade in the GDP of the GCC countries is around 100\%, except for Kuwait and Saudi Arabia. These shares are impressive and among the highest worldwide, as the share of merchandise trade in the GDP is $45 \%$ in the OECD countries, $67 \%$ in the Euro area, and $60 \%$ in the whole Middle East and North Africa (MENA) region. As shown in Tables 2, 3 and 4, Bahrain and the UAE have the most open economies among the GCC countries and their economies are highly dependent both on exports and imports.

GCC trade is concentrated on high-income countries, such as Japan, South

Table 1. Share of the GCC Merchandise Trade in the World Trade (\%)

\begin{tabular}{lcccccccccccc}
\hline & 1997 & 1998 & 1999 & 2000 & 2001 & 2002 & 2003 & 2004 & 2005 & 2006 & 2007 & 2008 \\
\hline Exports & 2.38 & 1.75 & 2.07 & 2.73 & 2.59 & 2.59 & 2.80 & 3.09 & 3.79 & 3.97 & 4.00 & 4.68 \\
Imports & 1.46 & 1.48 & 1.32 & 1.27 & 1.39 & 1.47 & 1.49 & 1.61 & 1.73 & 1.81 & 2.05 & 2.24 \\
\hline
\end{tabular}

Source: WTO International Trade Statistics, 2009

Figure 1. The Share of the GCC Trade in GDP

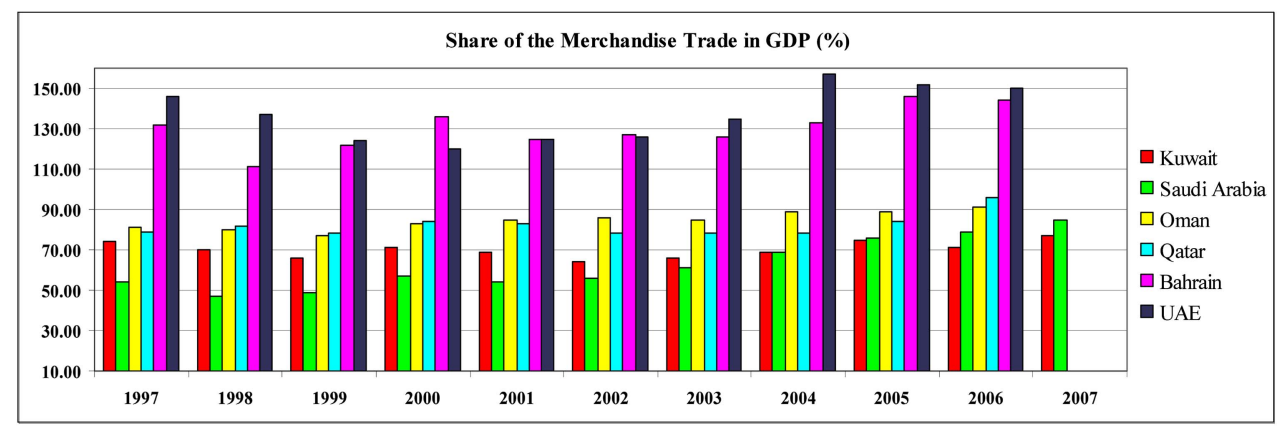


Table 2. Merchandise Trade of the GCC countries ( $\%$ of GDP)

\begin{tabular}{lccccccccccc}
\hline & 1997 & 1998 & 1999 & 2000 & 2001 & 2002 & 2003 & 2004 & 2005 & 2006 & 2007 \\
\hline Bahrain & 132 & 111 & 122 & 136 & 125 & 127 & 126 & 133 & 146 & 144 & - \\
Kuwait & 74 & 70 & 66 & 71 & 69 & 64 & 66 & 69 & 75 & 72 & 74 \\
Oman & 81 & 80 & 77 & 83 & 85 & 86 & 85 & 89 & 89 & 91 & - \\
Qatar & 79 & 82 & 78 & 84 & 83 & 78 & 78 & 78 & 84 & 96 & - \\
Saudi Arabia & 54 & 47 & 49 & 57 & 54 & 56 & 61 & 69 & 76 & 79 & 85 \\
UAE & 146 & 137 & 124 & 120 & 125 & 126 & 135 & 157 & 152 & 150 & - \\
\hline
\end{tabular}

Source: World Bank WDI Database

Table 3. Exports of the GCC countries (\% of GDP)

\begin{tabular}{lccccccccccc}
\hline & 1997 & 1998 & 1999 & 2000 & 2001 & 2002 & 2003 & 2004 & 2005 & 2006 & 2007 \\
\hline Bahrain & 79 & 65 & 79 & 89 & 82 & 82 & 82 & 92 & 100 & 99 & - \\
Kuwait & 53 & 44 & 46 & 56 & 51 & 45 & 52 & 57 & 64 & 65 & 65 \\
Oman & 50 & 42 & 49 & 59 & 57 & 58 & 57 & 57 & 63 & 63 & - \\
Qatar & 48 & 51 & 60 & 67 & 66 & 60 & 62 & 64 & 68 & 58 & - \\
Saudi Arabia & 39 & 30 & 35 & 44 & 40 & 41 & 46 & 53 & 61 & 63 & 65 \\
UAE & 83 & 73 & 70 & 73 & 73 & 73 & 79 & 90 & 93 & 91 & - \\
\hline
\end{tabular}

Source: World Bank WDI Database

Table 4. Imports of the GCC countries (\% of GDP)

\begin{tabular}{lccccccccccc}
\hline & 1997 & 1998 & 1999 & 2000 & 2001 & 2002 & 2003 & 2004 & 2005 & 2006 & 2007 \\
\hline Bahrain & 70 & 64 & 63 & 64 & 60 & 66 & 64 & 73 & 76 & 73 & - \\
Kuwait & 40 & 51 & 39 & 30 & 36 & 37 & 34 & 32 & 28 & 24 & 30 \\
Oman & 39 & 50 & 38 & 31 & 36 & 37 & 38 & 43 & 36 & 38 & - \\
Qatar & 36 & 40 & 26 & 22 & 29 & 28 & 28 & 28 & 33 & 37 & - \\
Saudi Arabia & 26 & 27 & 23 & 25 & 24 & 24 & 24 & 26 & 28 & 32 & 38 \\
UAE & 74 & 75 & 65 & 55 & 61 & 64 & 65 & 76 & 71 & 68 & - \\
\hline
\end{tabular}

Source: World Bank WDI Database

Korea, the US, and the EU. ${ }^{6}$ The merchandise imports of the GCC countries from these countries are mainly capital and technology intensive goods; machinery and transport equipment, such as power generation plants, railway locomotives and aircraft, and manufactured goods from the EU, aerospace products and parts, automobiles, various machinery, engines, turbines and power transmission equipment from the US, automobiles and auto parts from Japan, and automobiles,

\footnotetext{
${ }^{6}$ Currently, the EU and the GCC are negotiating a free trade agreement (FTA), aiming at a coordination and divergence not only in trade and investment related issues, but also in areas like human rights, terrorism and illegal immigration.
} 
various machinery, engines, iron and ships from South Korea. Also, with an increasing volume in the last decade, the GCC countries import manufactured goods and various machinery from China and India. ${ }^{7}$ On the other hand, GCC exports to these trade partners are heavily dominated by oil and oil products.

However, intra-GCC trade and trade with neighbouring countries are limited. The main reason of this is the fact that the countries of the region are similar in certain aspects, they rely heavily on the oil sector and have the highest concentrations in terms of sector contribution to GDP when compared to developed countries. ${ }^{8}$ In this respect, economic diversification is important for the GCC region for further intra-regional trade through diversified economies. ${ }^{9}$ In the recent years, the goal of decreasing vulnerability of the economies to the fluctuations in the oil and gas prices, high population growth and rising unemployment in the region increased the need for economic diversification. Significant amount of investment has been directed to services -especially to finance, tourism, transport, telecommunication and education-, construction and manufacturing sectors.

Albeit relatively low in trade volume, the GCC countries have a strong relationship with the rest of the Islamic countries due to common cultural and religious values, and economic interests, like being the members of OPEC and coordinating policies in oil markets. The economic relations with other Islamic countries also include labour movements, where the GCC countries receive a significant amount of labour force from Pakistan, Egypt and Indonesia. ${ }^{10}$ Egypt, Jordan and Pakistan have improved their economic relations with the GCC countries and they depend more on the GCC for remittances. ${ }^{11}$ In the recent years, the outflow of foreign direct investment from the GCC countries to other Islamic countries also increased significantly in services, real estate, infrastructure development, steel, shipping and energy sectors.

\section{A Modified Gravity Model of the GCC Trade}

The basic gravity model based on Newton's gravity equation states that the

\footnotetext{
${ }^{7}$ China and India have an energy cooperation with the GCC and they challenge to the US energy interest in the region.

${ }^{8}$ Abouchakra et al. (2008)

${ }^{9}$ Sturm et al. (2008)

${ }^{10}$ There is also a high ratio of immigration flow from India to the GCC.

${ }^{11}$ Middle East and Central Asia, Regional Economic Outlook, World Economic and Financial Surveys, IMF, May 2009.
} 
volume of trade between two countries is directly related to the product of their incomes, but inversely related to the distance between these countries. The application of gravity models to empirical international trade analysis was pioneered by Tingerben (1962) and then continued by Linnemann (1966) and many other scholars. In time, other explanatory variables have been added to the model as the measures of size of economies, geographical positions, cultural proximities, religion, and economic and regional trading arrangements.

There have been numerous panel data gravity models that explain the potential international trade flows between trading partners. Frankel (1997) provided the most comprehensive work on the trade theory and estimation techniques concerning the gravity model of bilateral trade. Bun and Klaassen (2003) emphasized the importance of dynamics in panel gravity models of trade flows and used ARDL $(1,1)$ dynamic panel structure to describe short run dynamics including time specific constants and treating country effects as fixed. They indicated that the LSDV estimates give better results than the GMM estimates. Zarzoso and Lehman (2003) estimated a gravity model on the trade potentials between Mercosur and the EU, where they found that fixed effects model (FEM) is superior to random effects model (REM) in explaining bilateral trade flows as they included more variables than the standard gravity model. Benedictis and Vicarelli (2004) underlined that robustness of a common panel functional form depends upon the choice of static or dynamic specification. They used generalised method of moments (GMM) to estimate export flows. Baier and Bergstrand (2004) analysed the effects of free trade agreements and evaluated the potential economic benefits of these agreements between the EU and the GCC countries. Ramos and Zarzoso (2005) argued that there appear some differences between rich and poor countries in gravity models and showed that trade flows are more sensitive to geographical and cultural variables for developing countries than for developed countries. Boughanmi (2008) studied the trade potential of GCC countries with a panel fixed effect gravity model. The paper aimed to investigate the import flows of the GCC countries with 69 partners over the period of 1990 to 2004 and found that the income variables and the dummy variable for the GCC countries are positive and significant supporting a high volume of intra-trade, but the EU and the US dummies are negative and significant, which indicates a low level of integration.

\section{A. Econometric methodology}

This paper analyzes the bilateral trade flows of each GCC country and attempts 
to develop a new approach to the gravity model by estimating bilateral trade flows in system equations with annual panel data from 1997 to 2007. Annual trade data is drawn from the UN COMTRADE database and the income data is drawn from IMF International Finance Statistics (IFS). All the variables, except for the dummies, are in natural $\log$ form.

The modelling framework departs from the common gravity model, as the trade equation and the country effect equation have been estimated simultaneously. In this sense, the total trade flows and the country effects are the endogenous variables in the model, whereas per capita real GDP of the home and partner countries, population, distance and dummies are the exogenous variables. Abbreviations and definition of variables are given in Appendix A.

Real total trade is defined in US dollars based on 2000 prices. In the analysis, first, GDP based on the purchasing power parity has been used to facilitate the cross country comparisons. However, the purchasing power parity ${ }^{12}$ (PPP) method directly reflects relative price of consumer and investment goods in different countries and also decreases the disparity in GDP between high and low income (GDP) countries. For that reason, the use of the PPP based income has caused measurement errors, as stated by Frankel (1997: 59). Therefore, the PPP based GDP has been replaced by real per capita GDP in US dollars based on 2000 prices.

Real per capita income measures the wealth or life standard of a country, such that if the income coefficient is significantly positive and greater than one, then an increase in the wealth of the host or the partner country raises the country's propensity to trade further.

Population is a proxy for the size of economy, thus the coefficient on the log of population is expected to be positive. In addition, the coefficient on population can capture the trend in the medium term and can explain the size and self-sufficiency of the partner countries according to the economies of scale and motivation of trade. In this analysis, trade partner's population has been included in the country effects equation as an explanatory variable, whereas the GCC country population has been used as the instrument ${ }^{13}$ in the GMM estimations in order to avoid the multicollinearity and autocorrelation problems.

Distance is the difference between capital cities and measured in kilometres. It is generally accepted as a proxy for transport costs, with a negative sign. Dummy

\footnotetext{
${ }^{12}$ OECD (2005), New GDP Comparisons Based on Purchasing Power Parities for the Year 2002.

${ }^{13}$ This variable with the first lagged values of trade and income, and the dummy variables are used as the instruments of the GMM model.
} 
variables are the GCC dummy, the EU-15 dummy, other oil producer countries dummy and ASIA dummy. The coefficient on each dummy variable reflects the major group effects on trade. Finally, the first lagged value of trade flow verifies the dynamic pattern of trade, stability of system and the robustness of the models.

The estimation approach of this paper includes two steps

1. Fixed effect trade models have been estimated in order to obtain unobservable partner country heterogeneity ${ }^{14}$ on trade for each GCC country, and then the trading partners have been ranked according to size of the estimated country effect coefficients for each GCC country.

2. Modified gravity models have been estimated through the system equations in order to evaluate the impact of each variable on bilateral trade for each GCC country. Accordingly, in this analysis:

i) Fixed effects trade models have been estimated by the OLS through 19972002 and 2003-2007 in order to control observed and unobserved characteristics of individual country effects by the following equation: LRT_GCC $\mathrm{GC}_{\mathrm{it}}=\varphi_{0}+\varphi_{1}$ LPCRI_GCC ${ }_{\mathrm{it}}+\varphi_{3}$ LRCRI_TR $_{\mathrm{jt}}+\omega_{\mathrm{t}}$.

ii) Validity of the fixed effects have been tested by the $\mathrm{F}$ and Hausman tests.

iii) Individual country effects variable has been defined for each of the GCC countries and these effects are assumed to be fixed during the estimation period.

iv) Individual country effects variable has been used to calculate country ranking and the Spearman's rank correlation coefficients.

v) Correlation coefficients have been calculated between (a.) the domestic country income and the FEM residuals, (b.) the partner country income and the FEM residuals, (c.) the local country income and the individual country effects, (d.) the partner country income and the country effects, and (e.) the country effects and the FEM residuals to ensure the correct specification.

vi) Static and dynamic trade models, for each country, have been estimated with the country effects equation simulataneously over the periods 1997-2002 and 20032007 by OLS and GMM methods.

$$
\begin{aligned}
& \text { LRT_GCC }{ }_{i t}=\alpha_{0}+\alpha_{1} \text { LCE_GCC } i t \\
& \text { LRT_GCC }{ }_{i t}=\beta_{0}+\beta_{1} \text { LCE_GCC }{ }_{i t}+\beta_{2} \text { LPCRI_GCC }{ }_{i t}+\beta_{3} \text { LPCRI_TP }{ }_{\mathrm{jt}}+\beta_{4} \text { LDIST } \\
& +\beta_{5} \text { LRT_GCC } \text { it } 1_{1}+\mathrm{u}_{2 \mathrm{t}} \\
& \text { LCE_GCC }{ }_{\mathrm{i}}=\theta_{0}+\theta_{1} \text { EUDUM }_{\mathrm{i}}+\theta_{2} \mathrm{GCCDUM}_{\mathrm{i}}+\theta_{3} \text { NONOPDUM }_{\mathrm{i}}+\theta_{4} \text { ASIADU }
\end{aligned}
$$

\footnotetext{
${ }^{14}$ It is called as the "individual country effect" throughout the paper. It is assumed that the intercept term differs from country to country, but it is constant over time.
} 


$$
\mathrm{M}_{\mathrm{i}}+\theta_{5} \mathrm{LPOP}_{-} \mathrm{TP}_{\mathrm{j}}+\varepsilon
$$

vii) Panel unit root tests have been applied to the residuals obtained from the estimated trade equation.

Each modified gravity model is based on the single country panel data approach, taking into account country specific intercept in international trade. For that reason, in the first step, the individual country effects for each GCC country have been captured by the fixed effect trade equation as a function of income variables since the FEM cannot covariate with the invariant variables. Invariant variables cause collinearity with the fixed effects in the single equation specification. ${ }^{15}$ In the second step, the trade and country effects equations have been estimated simultaneously for each GCC country.

It is believed that panel residual unit root tests help to distinguish a well specified model from a misspecified model. Since the error term of an econometric model varies with the structure of the model and the estimation method, the stationarity of the error term ensures that the linear combination of the variables is stationary. For these purposes the Im, Pesaran and Shin, and the Levin, Lin and Chu-t panel unit root tests ${ }^{16}$ with individual fixed effects and trend effects have been applied to estimated residuals.

\section{B. Discussion on estimated results}

The variables in this analysis have been assumed to encompass relevant information in the bilateral trade flows of the GCC countries with their trade partners. Trade partner countries are listed in Appendix B. The research question of this paper is that whether the GCC countries have sustained their trade partnerships and/or they have developed new trade relations after the 2003 Customs Union agreement. The primary concern of this analysis is to find a suitable econometric model for a given time dimension and data so that model selection depends mainly on the statistical/econometric properties of the series given the number of observations and the research question.

The first step of this analysis is the estimation of fixed effect models (FEM) by OLS in order to obtain the observed and unobserved characteristics of individual countries on bilateral trade. The selection of trade partners from different continents

\footnotetext{
${ }^{15}$ Zarzoso and Lehmann (2003) also suggest a two step estimation technique.

${ }^{16}$ The IPS test assumes that under the null hypothesis each series contains a unit root against at least one of the individual series is stationary. The LLC test assumes that under the null hypothesis the persistence parameters are common across cross sections against all series are stationary.
} 
with different language, religion, political, and development levels depends on the availability and reliability of data; whereas the selection of the estimation periods is determined in line with the GCC economic integration process. The six GCC members implemented a Customs Union in January 2003, eliminating all tariffs on trade and freeing movements of goods throughout the GCC.

The tes $\mathrm{t}^{17}$ results statistically support the FEM. The LS estimators are consistent as long as the error term in the fixed effects model is uncorrelated with the explanatory variables, supporting exogeneity of these variables. Table $\mathrm{C} 1$ in Appendix C, presents the correlation coefficients and supports the exogeneity of income variables over the two estimation periods facilitating the use of OLS estimators. ${ }^{18}$ Additionally, since there is a correlation between the trade partner's income and the country effect, then the FEM with cross section weights is the appropriate model. Furthermore, if the country effect is absorbed into the error term, then the error is correlated with the country effect. It has been found that all correlation coefficients are zero and the results favour the FEM for all countries.

Table C2 in Appendix C illustrates the Spearman's rank correlation coefficients in order to compare the position of trading partners between two set of data over the 1997-2002 and 2003-2007 periods. The overall results support a strong positive correlation exhibiting that the trade partners are roughly in the same order for each GCC country. However, for each GCC member, the composition of the top 15 partner countries changes noticeably after 2003. Asian countries China, India, Japan, S. Korea, Pakistan and Thailand; the EU countries the UK and Germany; the US; the GCC members Saudi Arabia and the United Arab Emirates have become important trade partners in all GCC trade.

The country rankings for each of GCC countries are presented in Appendix D, and they provide information for the following results:

1. Bahrain: The UAE is the most important trade partner in both periods. Saudi Arabia has become the second trading partner after 2003. Other GCC countries take place around first 25 in the rank. There are eight Asian countries among the first fifteen trade partners, namely India, China, Pakistan, Japan, Thailand, South Korea, Indonesia, and Malaysia. Kenya is above the US, the UK, and Germany. Iran is also a significant trading partner. Russia and Mexico place the last position

\footnotetext{
${ }^{17}$ The redundant fixed effects ( F) test and the correlated random effects (Hausman $\chi^{2}$ ) test. It is known that if there is a heterogeneity bias, then the LS estimators are inconsistent.

${ }^{18}$ If the fixed effects are constant over time or across countries, their effects are absorbed into the intercept, and hence these estimates will be unbiased and efficient.
} 
in the rank.

2. Kuwait: India has become the most important trading partner of Kuwait after 2003. The UAE has moved to the second position in the rank after 2003. There are seven Asian countries among the first fifteen partners, namely India, S. Korea, China, Japan, Indonesia, Singapore, and Thailand. The US has a position above Saudi Arabia, but below China and Japan. The UK, Germany and France have moved down in the rank after 2003. Israel gets the last position in the rank during the both periods.

3. Oman: The UAE is at top of the list after 2003. Seven Asian countries, specifically China, Thailand, India, S. Korea, Japan, Malaysia, and Pakistan, have become important partners following the UAE after 2003. Saudi Arabia takes a place below the Asian countries, but above the US, the UK and Germany. Other GCC countries get lower places in the rank. Both South Africa and Italy have become important trade partners. Australia has lost its position after 2003. Algeria and Israel share the last positions in the rank during 1997-2002 and 2003-2007 periods respectively.

4. Qatar: The UAE is the first and Japan is the second in the rank in both periods. India and S. Korea take the third and fourth positions in the rank, while Thailand, China, Singapore and Saudi Arabia keep their positions after 2003. Other GCC members get lower positions in the rank. The US and the UK go down, whereas Spain moves up in the rank after 2003. Slovakia and Israel have the weakest trade relationship in 1997-2002 and 2003-2007 periods respectively.

5. Saudi Arabia: China is the leading trade partner, while the United Arab Emirates and the US have a strong trade links after 2003. Eight Asian countries, i.e. India, Japan, S. Korea, Pakistan, Thailand, Indonesia, Philippines, and Singapore, are at the top of the rank mainly after 2003. Bahrain, Kuwait, Oman, and Qatar do not maintain a significant place in the country ranking in the post2003 period. South Africa and Jordan have moved to a higher position, whereas the UK, France, Netherlands, and Spain as the EU members could not keep their position after 2003. Israel holds the weakest trade relationship among the examined trade partners.

6. United Arab Emirates: Japan has become the most important trade partner during both periods. India has moved up and become the second trading partner after 2003. The US has come into ranking after China and S. Korea, but on top of Saudi Arabia. Iran has a higher rank than the EU member countries Germany, France, and Italy. Oman is among the top fifteen trade partners as a GCC member, 
but the other GCC members take lower orders in the rank. Israel is the last one in the rank for both periods.

In the second step of the analysis, for each GCC country, the bilateral trade equation has been determined by the host and partner countries' real per capita incomes, individual country effects ${ }^{19}$ and distance variables with a constant term, whereas the country effect equation has been defined in terms of dummies and the partner countries' population. That is, while the country effects are allowed to vary from one country to another as a function of the specific time invariant variables, the slope coefficients are assumed to be constant within country and time dimension. Accordingly, the bilateral trade flows and the individual country effects equations have been estimated simultaneously by OLS $^{20}$ and GMM within the modified gravity model assuming that $\theta_{1}=1 .{ }^{21}$

Individual country estimation results have been reported in Appendix $E^{22}$ in Tables 1 to 6 . The first lag of dependent variable has been added to the behavioural trade equation when OLS is used, whereas it has been used as an instrument where GMM is used. Since the fixed effects model is less sensitive to violation of the strict exogeneity assumption, lag variable is expected to reduce correlation and also to capture the dynamics of trade. The static and dynamic OLS results are reported in first and second columns, and the static model GMM results are reported in third column. The OLS estimates of the static and dynamic trade equations for each GCC are similar supporting the robustness of OLS results. The coefficient on the lagged trade variable is always less than one and insignificant for some countries, confirming the stability of each equation. The GMM estimates are similar to the OLS estimates for all GCC, except for the coefficient on other oil producer countries dummy. A comparison of the estimation results allows us to conclude that all model specifications are better through the 2003 and 2007 period. This is also confirmed by the residuals panel unit root tests ${ }^{23}$ in Appendix F.

\footnotetext{
${ }^{19}$ Individual country effect is the cross section term obtained from the FEM, and assumed to be constant and specific to the individual country over the estimation periods.

${ }^{20}$ OLS results are identical to the WLS results.

${ }^{21}$ The effects of the EU, GCC, other oil producer countries, ASIA dummies and the population of the trade partner on bilateral trade flows are allowed to occur through the country effect variable in the trade equation.

${ }^{22}$ The estimated intercept term in the trade equation for each GCC country is not statistically significant from 2003 to 2007 period, except Qatar; but it is significant during the 1997-2002 period for KUW, OMA, QAT, SAU, and UAE where the OLS is used. These results are not reported.

${ }^{23}$ Since Im-Pesaran-Shin (IPS) test has a better performance in finite samples and the Levin-Lin-Chu (LLC) test has a better performance for the unbalanced panels, both tests have been used to test for common and individual unit roots under the null hypotheses. Lag selection is based on SIC.
} 
For a comparative country analysis, it would be better to examine the static estimation and compare the role of each variable in the two estimation periods. The role of real per capita income in determining bilateral trade is a critical issue in view of the economies of scale and motivation of trade. The model analyses the effects of the real per capita incomes of both the GCC countries and the trade partners on their trade patterns. The OLS and GMM coefficients of the real per capita income of the GCC countries are significant and positive in both periods however the values have increased in the second period. In the 1997-2002 period, only Bahrain and Saudi Arabia have coefficient values more than one, but in the 2003-2007 period, the coefficient of the domestic real per capita income exceed one in all GCC countries. This implies that, increases in the wealth of the GCC countries have been reflected to trade of these countries in proportionally higher values. Over the last five years, for every GCC country, an increase in the per capita income has created a multiplier effect on trade. ${ }^{24}$ As the GCC countries got wealthier, their demand for high-valued and capital intensive imported goods like machinery, mechanical appliances and automobiles increase, and this directly led to the increases in imports. This result is also consistent with the economic fact that richer countries tend to trade more than poor ones.

The estimated coefficients on the real per capita income of trade partner countries display a slightly different trend. Except for Bahrain and Qatar, the impact of the increases in the real per capita incomes of the trade partners is relatively low, even negative in some countries for the first period. In the second period, on the other hand, the coefficient values increase significantly to positive values. Interestingly, while Bahrain had the highest coefficient value on the trade partner's per capita income level in the first period, the coefficient value almost halved in the second period. Positive coefficient values imply that trade volumes of the GCC countries rise as their trade partners' income increase. Still, this rise in trade is proportionately lower than the increase in the partner's income, as the estimated values are less than one. This is mainly the result of the relatively inelastic demand structure of oil. Oil demand from the GCC countries is not affected by the income fluctuations noticeably since the global oil demand has been driven mainly by growth in emerging countries including the non-GCC oil producers and the GCC members. This intuition is also validated with the lowest coefficient values on the partner country real per capita income for two large oil

\footnotetext{
${ }^{24} 2003-2007$ period includes the golden years for the GCC due to favourable conditions such as the rise in oil prices, huge investment projects for economic diversification and the strong global equity market.
} 
producers, Saudi Arabia and the UAE.

Contrary to the common gravity equation for trade, the coefficient of the distance variable is commonly insignificant in all periods and for all countries. One reason of this insignificancy is the type of traded goods and the geographical location of the GCC countries. The GCC is surrounded by either relatively lowincome countries or countries that have oil reserves. The GCC countries mainly export oil, fuels, gas, lubricants, energy intensive products such as petrochemicals and aluminium to relatively rich countries like the EU, Japan, South Korea, and the US where low transport costs give GCC producers some competitive advantage. ${ }^{25}$ Moreover, the GCC countries import high-tech and manufactured products like machinery and mechanical appliances, vehicles, electrical machinery and equipment. Since these are not produced in the neighbouring countries, they are imported both from developed countries, such as the US, Japan, the EU and S. Korea, and developing countries with low labour costs, like China, India, Thailand, Malaysia, and Pakistan. Second reason is related with the measurement method of geographical distance, since most of exports and imports are realized by shipments as a result of technological progress in sea transport facilities. Currently, the cost of transport is related to the transport infrastructure rather than distance. Third reason is the inclusion of the GCC dummy which is highly correlated with the distance variable and thus it acts as an adjacency variable in the system. Fourth reason is the sufficiently deep bilateral trade agreements and arrangements with the GCC countries which are represented by the Asia and EU dummies. These effects weaken the role of distance on trade. Finally, a hypothetical reason ${ }^{26}$ might be the impact of migration flows to the GCC economies which are positively and significantly linked to the trade flows reducing the role of distance. Consequently, in this context, it is not surprising to obtain an insignificant coefficient on distance variable since technological developments in production, communication and transportation facilities have made transport easier, leaving distance variable as an inefficient proxy for transport cost in the gravity model.

The estimated coefficients on the GCC, EU and Asia dummies are generally highly significant revealing the importance of regional or block effects on bilateral

\footnotetext{
${ }^{25}$ J. Rollo, Prospects for an EU-Gulf Cooperation Council Free Trade Area, The World's First Region to Region FTA, Briefing Paper, Chatham House and University of Sussex, April 2008.

${ }^{26}$ The author has been examining the trade and migration relationship within another work, and believes in the existence of a strong relationship between them. It is known that there is an immigration flow from Asian countries (mainly from India and Pakistan) to the GCC countries.
} 
trade. Even though the GCC dummies for all GCC members are significant and positive in both periods, the coefficient values are lower in the second period (except for Saudi Arabia) revealing that the proposed GCC Customs Union has not proceeded as expected. The EU dummy is not significant for Bahrain, but it is highly significant for the other members after 2003. Noticeably, the decrease in the magnitudes of the coefficients after 2003 validates the compressed role of the EU countries in the GCC trade flows. The coefficient on the other oil producer countries dummy variable is insignificant for Kuwait, Oman and Saudi Arabia; negative for Bahrain and Qatar, but positive for the UAE throughout the first period. In the second period, it becomes insignificant only for Saudi Arabia, is still positive for the UAE, and negative for the other countries. The reason of the positive coefficient for the UAE is that the UAE imports oil from non-GCC oil producer countries, mainly from Iran and re-export to other countries. Asian dummies appear very high and significant for all the GCC countries supporting their strong trade connection in both periods. This is mainly due to the fact that four of the top ten oil importers, Japan, China, South Korea and India are in the Asia region and they extensively export from the GCC countries. These results are consistent with the country ranking approach in Appendix D.

Coefficients on the partner country population are always less than one and positive, having a positive effect on the GCC trade. The coefficient is higher in the second period, with the exception of Bahrain. This is also an expected outcome in view of the oil based trade structure of the GCC countries where every increase in the population of the trade partner accompanies with a rise in the demand for energy.

The year 2003 has marked a turning point in the economic policies of the GCC countries. Two important conjunctural changes have taken place in 2003; it was a turning point in the intra-GCC trade as the member countries have agreed on a Customs Union agreement, and also a turning point in the GCC's trade with the $\mathrm{EU}$ as the economic relations accelerated after the first Economic Dialogue meeting in 2003. However, contrary to the expected result, neither of these developments have been significantly reflected to the trade patterns of the GCC countries. On the other hand, high economic growth in Asian countries such as China, India and South Korea, accompanied by their demand for fossil fuels carried these countries to higher positions in the country ranking of trade as seen in the Appendix D.

Another important difference between pre and post 2003 periods is the increase in the significance and the magnitude of the Asian dummy in the model, whereas 
GCC and EU dummies lost their significance to some extent. Parallel to the result mentioned above, trade flows from and to the GCC have been directed to regions with relatively higher economic growth, but not to the political decisions like the Customs Union and the economic dialogue with the EU. Thus, both moves aimed to foster trade within the region and with the EU have failed to reach their goals, and have lagged behind the effect of the economic dynamism in the Asia region.

\section{Conclusion}

In this paper, the research question is whether the trade flows of each GCC country with their partners have sustained or have developed new relations mainly after the introduction of the Customs Union agreement of the GCC in 2003. The research approach differs from other gravity model studies. Usual gravity models include highly correlated (multicollinearity) proximities, such as distance, population and dummies. So a single country gravity equation cannot be estimated with the time invariant variables within the fixed effect model. In this study, the application of simultaneous estimation method has been found rather convenient with regard to the trade and country effects equations using annual panel data. The gravity model as a function of distance and income variables; the country effects model as a function of dummies and the partners' populations have been estimated for each GCC country. The individual country effects variable has been obtained from the fixed effect trade model, defined as a function of domestic and foreign incomes. Two equations system has been estimated separately for each GCC over two sample periods by the Least Squares and Generalised Method of Moments under the assumption of the presence of cross section heteroskedasticity and the robust standard errors.

The results of the estimated models for the periods 1997-2002 and 2003-2007 reveal some important facts regarding the trade patterns of the GCC countries. First of all, distance variable, the key determinant of the gravity model, is insignificant for all GCC countries. On the other hand, incomes and time invariant variables are the important determinants of trade flows in this analysis.

Overall, this empirical analysis provides four important outcomes:

A. Fixed effect panel models provide information on individual country effects. Country ranking approach makes the trade destination of each GCC country known. The results reveal that the overall rank of trade partners has not changed significantly from 1997-2002 to 2003-2007 period. However, the order of top 
fifteen trade partners has changed significantly as Asian countries have moved above the EU countries and the US after 2003.

B. The trade flows of the GCC countries are positively related to the trade partner's per capita income, as expected from a gravity model specification. Accordingly, with the global economic growth in the last decade, until the recent economic crisis, the GCC countries notably increased their trade activities and the standard of living.

C. The model shows that, contrary to the core of the gravity model where trade between two countries decreases as distance between them increases, the trade pattern of the GCC countries show a different trend. Exports and imports of the GCC countries are related to the wealth of the partner countries, but not to their distance, mainly due to the nature of their exported and imported goods, the characteristic of the region and developments in transportation facilities.

D. Comparing the results of the first period with the post-2003 period, both the rise in the positions of the Asian countries in the country ranking, and the increase in the relative importance of the Asian dummy compared to the GCC and EU dummies, we can conclude that neither the GCC Customs Union agreement, nor the launch of the economic dialogue with the EU could surpass the effect of the high economic growth in China, India and South Korea that accompanied by increasing trade.

The results reveal some significant implications on the structure of bilateral trade flows of the GCC countries and on the impacts of the economic, cultural and political issues during trade negotiations with the GCC countries. It is found that the integration process after the year 2003 has not improved the intra-GCC trade share considerably. Moreover, the important trade partners of the GCC countries- the EU countries and the US- are replaced by the Asian countries- China, India, South Korea and Japan- after 2003. These results reveal the composition of the traded goods and the role of bilateral trade agreements, mainly with the Asian countries.

\section{Acknowledgements}

First version of this paper was presented at the $29^{\text {th }}$ Annual Meetings of the Middle East Economic Association (MEEA) in conjunction with the Allied Social Science Associations (ASSA) Annual Meeting of the American Economic Association, 2 January 2009, San Francisco, CA, USA. 


\section{References}

Abouchakra, R., Moujaes, C. N., Najjar, M. R., and Shediac, R. (2008), Economic Diversification: The Road to Sustainable Development, Booz \& Company.

Antonucchi, D., Manzocchi, S. (2006), Does Turkey Have A Special Trade Relation with the EU? A Gravity Model Approach, Economic Systems, 30, 157-169.

Australian Department of Foreign Affairs and Trade, More than Oil: Economic Developments in Bahrain, Kuwait, Oman, Qatar and the UAE, Canberra BP, 2007.

Baier, S. I. and Bergstrand, J. B. (2004), Trade Agreements and Trade Flows: Estimating the Effects of Free Trade Agreements on Trade Flows with an Application to the European Union-Gulf Cooperation Council Free Trade Agreement, European Economy, Economic Papers, 214.

Benedictis, L. D., Vicarelli. (2004), C., Trade Potentials in Gravity Panel Data Models, University of Macerata, Italy.

Boughanmi, H. (2008), The trade Potential of the Arab Gulf Cooperation Countries (GCC): A Gravity Model Approach, Journal of Economic Integration, 23(1), 42-56.

Bun, M.J.G., Klaassen, F.J.G.M. (2002), The Importance of Dynamics in Panel Gravity Models of Trade, University of Amsterdam, Netherlands.

Chirullo, M. and Guerrieri, P. (2002), GCC-EU Relations and Trade Integration Patterns, European Robert Schuman Centre for Advanced Studies, Policy Papers, 02/5, University Institute, Florence.

Egger, P. (2000), $A$ Note on the Proper Econometric Specification of the Gravity Equation, Economic Letters, 66, 25-31.

Egger, P., Pfaffermayr M. (2002), Long Run and Short Run Effects in Static Panel Models, University of Innsbruck, Austria.

Frankel, J. (1997), Regional Trading Blocks in the World Economic System, Washington DC, Institute for International Economic Research.

Harris, M.N., Matyas, L. (1998), The Econometrics of Gravity Models, Melbourne Institute Working Paper, 5/98, Australia.

Hertog, S. (2007), EU-GCC Relations in the Era of the Second Oil Boom, European and the Middle East, CAP Working Paper, December.

Hirsch, S. and Hashai, N. (2000), The Arab-Israeli Trade Potential: The role of DistanceSensitive Products, International Trade Journal, XIV.

Insel, A., Tekce, M. (2009), Bilateral Trade Flows Of The Gulf Cooperation Council Countries: A Gravity Model Approach, Topics in Middle Eastern and North African Economies, Vol.11, Middle East Economic Association and Loyola University Chicago, September.

Insel, A., Tekce, M. (2010), Modelling the Trade Flows of The Gulf Cooperation Council Countries: A New Approach to Gravity Model, Turkish Economic Association Discussion Paper, 2010/2.

Insel, A., Tekce, M. (2010), Econometric Analysis of the Bilateral Trade Flows in the Gulf 
Cooperation Council Countries, MPRA Paper, No.22184, April.

Linnemann, H. (1966), An Econometric Study of International Trade Flows, Amsterdam.

Ramos, L.M., Zarzoso, I. M., (2005), Does Heterogeneity Matter in the Context of the Gravity Model?, Economic Bulletin, 6(10), 1-7.

Statistical Review of World Energy, London IMF, Regional Economic Outlook, Middle East and Central Asia, Washington, D.C, 2007.

Sturm, M., J. Strasky, P. Adolf and D. Peschel. (2008), The Gulf Cooperation Council countries: Economic Structures, Recent Developments and Role in the Global Economy, European Central Bank Occasional Paper Series, No. 92, Frankfurt.

Tang, D. (2003), Economic Integration Among the Asia-Pacific Economic Cooperation Countries: Linder Effect on Developed and Developing Countries (1985-1999), The International Trade Journal, Vol. XVII, 1.

Tinbergen, J. (1962), Shaping the World Economy: Suggestions for an International Economic Policy, The Twentieth Century Fund.

Zarzoso, I M. and Lehmann, F. N. (2003), Augmented Gravity Model: An Empirical Application to Mercosur-European Union Trade Flows, Journal of Applied Economics, 6(2), 291-316.

\section{Appendices}

\section{A. Abbreviations and Definitions}

FEM : Fixed effects model

BAHR : Bahrain

KUW : Kuwait

OMA : Oman

QAT: Qatar

SAU : Saudi Arabia

UAE : United Arab Emirates

$\mathbf{G C C}_{\mathbf{i}}$ :Gulf Cooperation Council, i=BAHR, KUW, OMA, QAT, SAU, UAE

$\mathbf{L C E}_{\mathbf{i}}$ : Natural log of individual country effect obtained from the related FEM.

LRT : Natural of log of real total trade (constant in 2000=100 US\$)

LPCRI : Natural log of per capita real GDP (constant in 2000=100 US\$)

LDIST $_{\mathrm{i}}$ : Natural log of distance between capital cities.

LPOP : Natural log of population

LCE : Natural log of estimated country effect 
$\mathbf{T P}_{\mathbf{j}}$ : Trade Partner, $\mathrm{j}=1, . ., 56$ for BAHR;

$$
\begin{aligned}
& j=1, \ldots 61 \text { for QAT; } \\
& j=1, . .65 \text { for SAU; } \\
& j=1, . ., 67 \text { for UAE. }
\end{aligned}
$$

$\mathrm{j}=1, . ., 61$ for $\mathrm{KUW}$

EUDUM $_{\mathbf{i}}$ : Takes 1 if the partner is the Members of EU, otherwise 0.

15 EU Members:

Austria

Belgium/Luxemburg

Denmark

Finland

France

Germany

Greece

Ireland

Italy

Netherlands

Portugal

Spain

Sweden

UK

GCCDUM $_{\mathbf{i}}$ : Takes 1 if the partner is the member of GCC; otherwise 0.

ASIADUM $_{i}$, Takes 1 if the partner is the Asian country; otherwise 0 .

Asian Countries:

China

Indonesia

Hong Kong

India

Japan

S. Korea

Malaysia

Pakistan

Philippines

Thailand

Singapore 
NONOPDUM $\mathbf{M}_{\mathbf{j}}$ : Takes 1 if the partner is the (non-GCC) oil producer; otherwise 0. Top 20 World Oil Producers:
Algeria
Brazil
Canada
Iran
Mexico
Norway
Russia
US

(Except Saudi Arabia, UAE, Kuwait, Oman, and UK, China, and Indonesia)

\section{B. List of the Partner Countries}

\begin{tabular}{|c|c|c|c|c|c|c|c|c|c|c|c|}
\hline $\mathbf{A H}$ & & KUW & & OMA & & $\overline{\text { QAT }}$ & Partner & SAU & Partner & UAE & Partner \\
\hline 1 & Algeria & 1 & Algeria & 1 & Algeria & 1 & Algeria & 1 & Algeria & 1 & Algeria \\
\hline 2 & Arge & 2 & Arge & 2 & Arg & 2 & Argen & 2 & Argen & 2 & Arge \\
\hline 3 & Austı & 3 & Austr & 3 & & & Austr & J & & 3 & \\
\hline 4 & Aust & 4 & & 4 & & 4 & & 4 & & 4 & \\
\hline 5 & Belg/Lux. & 5 & Bahr & 5 & & 5 & & 5 & & 5 & Irain \\
\hline 6 & Brazil & 6 & Belg/I & 6 & Belg & 6 & Belg & 6 & & 6 & \\
\hline 7 & Can & 7 & Bulg & 7 & & 7 & $\mathrm{Bra}$ & 7 & $\mathrm{Bra}$ & 7 & Brazil \\
\hline 8 & Chile & 8 & Canada & 8 & Can & 8 & & 8 & $\mathrm{Bu}$ & 8 & aria \\
\hline 9 & Chin & 9 & & 9 & & & & & & 9 & \\
\hline 10 & Cypr & 10 & & 10 & $\mathrm{Ch}$ & 10 & & 10 & & 10 & $\mathrm{Ch}$ \\
\hline 11 & Czech Rep & 11 & Сyp & 11 & $\mathrm{Cy}$ & 11 & & 11 & & 11 & \\
\hline 12 & $\mathrm{D}$ & 12 & $\mathrm{Cze}$ & 12 & & 12 & Cze & 12 & Col & 12 & \\
\hline 13 & & 13 & Denr & 13 & Den & 13 & Der & 13 & & 13 & ech \\
\hline 14 & Finland & 14 & Egypt & 14 & Egy & 14 & Eg. & 14 & & 14 & nark \\
\hline 15 & & 15 & & 15 & & 15 & & 15 & & 15 & \\
\hline 16 & Germany & 16 & France & 16 & Frar & 16 & Finl & 16 & Ethi & 16 & Ethiopia \\
\hline 17 & Greece & 17 & Gern & 17 & Ger & 17 & France & 17 & & 17 & Finland \\
\hline 18 & Hong Kong & 18 & & 18 & & 18 & Gerr & 18 & & 18 & France \\
\hline 19 & Hungary & 19 & Guatemala & 19 & H. Kc & 19 & Greece & 19 & Germany & 19 & Germany \\
\hline 20 & & 20 & Hong Kong & 20 & Hungary & 20 & Hong Kong & 20 & & 20 & Ghana \\
\hline 21 & Indonesia & 21 & Hungary & 21 & & 21 & Hungary & 21 & Greece & 21 & Greece \\
\hline 22 & Iran & 22 & India & 22 & Indonesia & 22 & India & 22 & Guatemala & 22 & Hong Kon \\
\hline
\end{tabular}




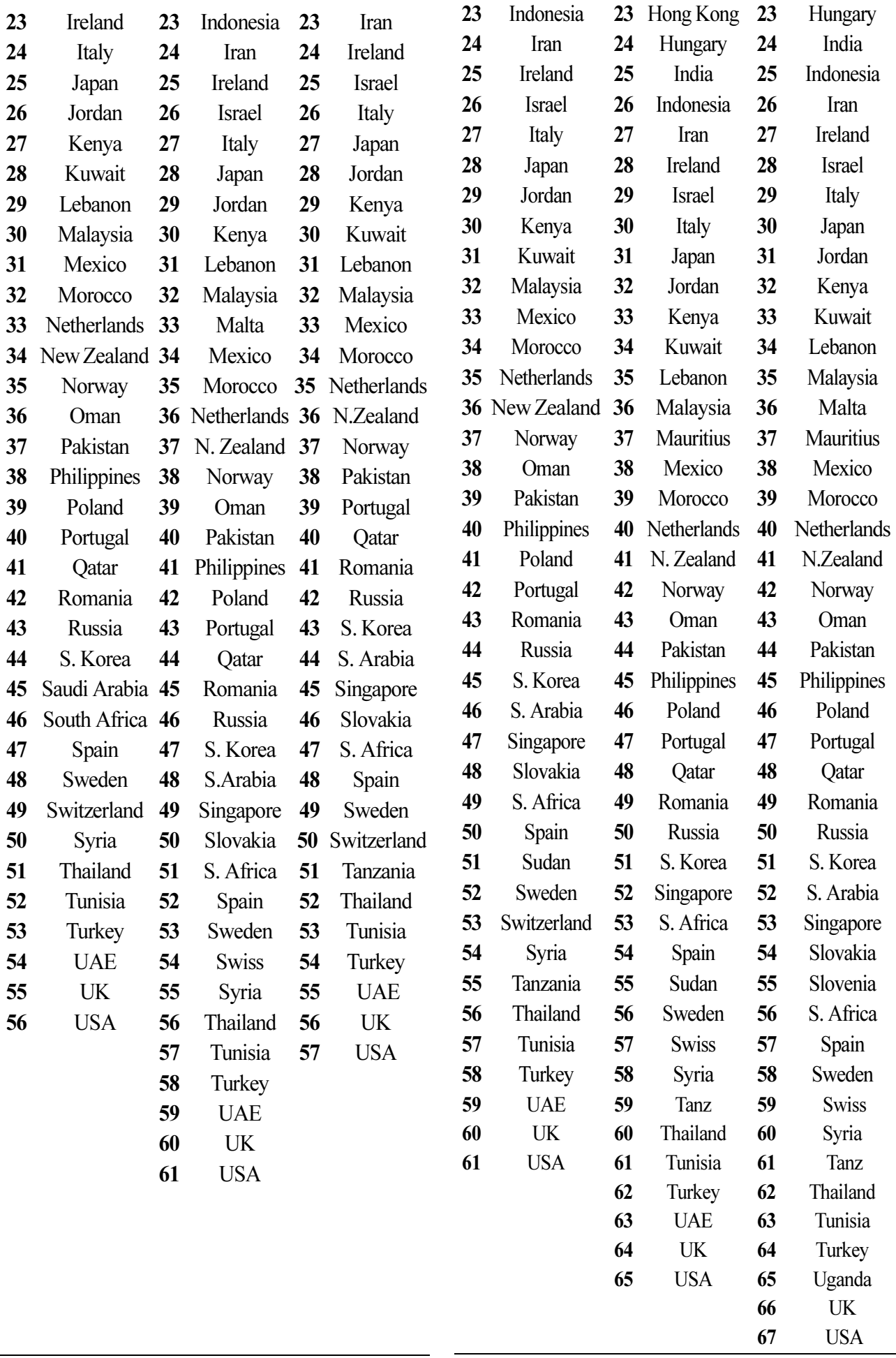




\section{Simple and Spearman's Correlation Coefficients}

Table C1. Correlation Coefficients

\begin{tabular}{|c|c|c|c|c|}
\hline & & & & \\
\hline & & & & \\
\hline & residual & LCE & residual & LCE \\
\hline$\overline{\text { LPCRI }}$ & & & & \\
\hline BAHR & 0.051 & 0.000 & 0.058 & -0.013 \\
\hline KUW & 0.012 & 0.010 & 0.029 & -0.011 \\
\hline OMA & 0.038 & -0.006 & 0.061 & -0.003 \\
\hline QAT & -0.002 & 0.002 & -0.003 & 0.034 \\
\hline SAU & -0.013 & 0.008 & 0.007 & -0.005 \\
\hline UAE & 0.015 & -0.003 & 0.002 & -0.007 \\
\hline$\overline{\text { LPCRI }}$ & & & & \\
\hline BAHR & 0.005 & -0.454 & 0.006 & -0.311 \\
\hline KUW & 0.000 & 0.171 & 0.004 & -0.245 \\
\hline OMA & 0.000 & 0.238 & 0.008 & -0.328 \\
\hline QAT & -0.002 & -0.081 & 0.001 & -0.214 \\
\hline SAU & -0.001 & 0.242 & 0.001 & -0.174 \\
\hline UAE & -0.003 & 0.342 & -0.008 & 0.053 \\
\hline$\overline{\mathrm{LCE}}$ & & & & \\
\hline BAHR & 0.000 & & 0.000 & \\
\hline KUW & 0.000 & & 0.000 & \\
\hline OMA & 0.000 & & 0.000 & \\
\hline QAT & 0.000 & & 0.000 & \\
\hline SAU & 0.000 & & 0.000 & \\
\hline UAE & 0.000 & & 0.000 & \\
\hline
\end{tabular}

Table C2. Spearman's Country Rank Correlation Coefficients

\begin{tabular}{lcc}
\hline Country & $\begin{array}{c}\text { Number of } \\
\text { trade partners }\end{array}$ & Coefficient \\
\hline Bahrain & 56 & 0.928 \\
Kuwait & 61 & 0.884 \\
Oman & 57 & 0.971 \\
Qatar & 61 & 0.960 \\
Saudi Arabia & 65 & 0.906 \\
United Arab Emirates & 67 & 0.931 \\
\hline
\end{tabular}


D. Country Ranking

\begin{tabular}{|c|c|c|c|c|c|c|c|}
\hline \multirow{2}{*}{$\begin{array}{l}\text { BAHRAIN } \\
1997-2002\end{array}$} & \multicolumn{7}{|c|}{ KUWAIT } \\
\hline & COUNTRY & 2003-2007 & COUNTRY & $1997-2002$ & COUNTRY & 2003-2007 & COUNTRY \\
\hline 1 & UAE & 1 & UAE & 1 & Japan & 1 & India \\
\hline 2 & India & 2 & Saudi Arabia & 2 & USA & 2 & UAE \\
\hline 3 & Pakistan & 3 & India & 3 & S. Korea & 3 & Pakistan \\
\hline 4 & Saudi Arabia & 4 & China & 4 & Singapore & 4 & S. Korea \\
\hline 5 & China & 5 & Kenya & 5 & Netherlands & 5 & China \\
\hline 6 & Kenya & 6 & USA & 6 & UK & 6 & Japan \\
\hline 7 & Indonesia & 7 & Pakistan & 7 & Germany & 7 & Indonesia \\
\hline 8 & Thailand & 8 & Japan & 8 & Pakistan & 8 & USA \\
\hline 9 & USA & 9 & Thailand & 9 & India & 9 & Singapore \\
\hline 10 & S. Korea & 10 & S. Korea & 10 & France & 10 & Netherlands \\
\hline 11 & Japan & 11 & UK & 11 & Saudi Arabia & 11 & Egypt \\
\hline 12 & Malaysia & 12 & Germany & 12 & Italy & 12 & Saudi Arabia \\
\hline 13 & UK & 13 & Indonesia & 13 & Indonesia & 13 & UK \\
\hline 14 & Iran & 14 & Malaysia & 14 & China & 14 & Thailand \\
\hline 15 & Brazil & 15 & Iran & 15 & UAE & 15 & Germany \\
\hline \multicolumn{8}{|c|}{ QATAR } \\
\hline 1997-2002 & COUNTRY & 2003-2007 & COUNTRY & $1997-2002$ & COUNTRY & 2003-2007 & COUNTRY \\
\hline 1 & Japan & 1 & UAE & 1 & UAE & 1 & $\overline{\mathrm{UAE}}$ \\
\hline 2 & UAE & 2 & China & 2 & Japan & 2 & Japan \\
\hline 3 & S. Korea & 3 & Thailand & 3 & S. Korea & 3 & India \\
\hline 4 & China & 4 & India & 4 & India & 4 & S. Korea \\
\hline 5 & Thailand & 5 & S. Korea & 5 & Thailand & 5 & Thailand \\
\hline 6 & USA & 6 & Japan & 6 & China & 6 & China \\
\hline 7 & UK & 7 & Malaysia & 7 & Singapore & 7 & Singapore \\
\hline 8 & Singapore & 8 & Pakistan & 8 & USA & 8 & Pakistan \\
\hline 9 & Saudi Arabia & 9 & Saudi Arabia & 9 & Saudi Arabia & 9 & Saudi Arabia \\
\hline 10 & Germany & 10 & USA & 10 & Philippines & 10 & France \\
\hline 11 & Italy & 11 & UK & 11 & Pakistan & 11 & USA \\
\hline 12 & France & 12 & Germany & 12 & UK & 12 & Spain \\
\hline 13 & Malaysia & 13 & Singapore & 13 & France & 13 & Philippines \\
\hline 14 & India & 14 & South Africa & 14 & Indonesia & 14 & Germany \\
\hline 15 & Australia & 15 & Italy & 15 & Germany & 15 & UK \\
\hline \multicolumn{4}{|c|}{ SAUDI ARABIA } & \multicolumn{4}{|c|}{ UNITED ARAB EMIRATES } \\
\hline $1997-2002$ & COUNTRY & 2003-2007 & COUNTRY & $1997-2002$ & COUNTRY & 2003-2007 & COUNTRY \\
\hline 1 & USA & 1 & China & 1 & Japan & 1 & Japan \\
\hline 2 & Japan & 2 & UAE & 2 & S. Korea & 2 & India \\
\hline 3 & S. Korea & 3 & USA & 3 & USA & 3 & China \\
\hline 4 & Singapore & 4 & India & 4 & UK & 4 & S. Korea \\
\hline 5 & UK & 5 & Japan & 5 & Singapore & 5 & USA \\
\hline 6 & France & 6 & S. Korea & 6 & Germany & 6 & Thailand \\
\hline 7 & China & 7 & Pakistan & 7 & France & 7 & UK \\
\hline 8 & Italy & 8 & Thailand & 8 & Oman & 8 & Saudi Arabia \\
\hline 9 & Germany & 9 & Indonesia & 9 & Italy & 9 & Iran \\
\hline 10 & India & 10 & Philippines & 10 & Hong Kong & 10 & Germany \\
\hline 11 & Netherlands & 11 & Singapore & 11 & India & 11 & Pakistan \\
\hline 12 & UAE & 12 & South Africa & 12 & Saudi Arabia & 12 & Singapore \\
\hline 13 & Indonesia & 13 & Italy & 13 & China & 13 & France \\
\hline 14 & Spain & 14 & Jordan & 14 & Thailand & 14 & Oman \\
\hline 15 & Pakistan & 15 & Germany & 15 & Iran & 15 & Italy \\
\hline
\end{tabular}


E. Estimation Results

Table 1. BAHRAIN

\begin{tabular}{|c|c|c|c|}
\hline \multirow{2}{*}{$\begin{array}{l}\text { 1997-2002: } \\
\text { Dependent variable: LRT_BAHR }\end{array}$} & \multicolumn{2}{|c|}{ OLS } & \multirow[t]{2}{*}{ GMM } \\
\hline & (1) & (2) & \\
\hline $\mathrm{LCE}$ & $1.000[0.013]$ & $1.017(0.054)$ & $1.016[0.015]$ \\
\hline LPCRI_BAHR & $1.207[0.376]$ & $1.251(0.382)$ & $1.378[0.550]$ \\
\hline LPCRI_TP & $0.811[0.020]$ & $0.825(0.047)$ & $0.823[0.019]$ \\
\hline LDIST $^{-}$ & $0.000[0.027]$ & $0.008(0.029)$ & $-0.001[0.037]$ \\
\hline LRT_BAHR $_{t-1}$ & & $-0.016(0.052)$ & \\
\hline \multicolumn{4}{|l|}{ Depēndent variable: LCE_BAHR } \\
\hline EUDUM & $-0.076[0.185]$ & $-0.076[0.185]$ & $0.064[0.156]$ \\
\hline GCCDUM & $2.949[0.267]$ & $2.949[0.267]$ & $3.124[0.208]$ \\
\hline NONOPDUM & $-1.255[0.234]$ & $-1.255[0.234]$ & $-0.283[0.292]$ \\
\hline ASIADUM & $1.187[0.232]$ & $1.187[0.232]$ & $1.052[0.177]$ \\
\hline LPOP_TP & $0.743[0.054]$ & $0.743[0.054]$ & $0.874[0.039]$ \\
\hline $\mathrm{N}$ & 667 & 661 & 652 \\
\hline$\overline{\mathrm{R}}_{1}^{2}$ & 0.943 & 0.943 & 0.943 \\
\hline$\overline{\mathrm{R}}_{2}^{2}$ & 0.578 & 0.578 & 0.542 \\
\hline $\mathrm{SER}_{1}$ & 0.439 & 0.441 & 0.441 \\
\hline $\mathrm{SER}_{2}$ & 1.287 & 1.287 & 1.352 \\
\hline Mean of LRT_BAHR & 17.115 & 17.104 & 17.104 \\
\hline Mean of LCE_BAHR & 0.011 & 0.011 & 0.000 \\
\hline 2003-2007: & \multicolumn{2}{|c|}{ OLS } & GMM \\
\hline Dependent variable: LRT_BAHR & (1) & (2) & \\
\hline LCE & $1.000[0.016]$ & $0.842(0.061)$ & $1.003[0.016]$ \\
\hline LPCRI_BAHR & $1.539[0.178]$ & $1.351(0.192)$ & $1.397[0.192]$ \\
\hline LPCRI_TP & $0.458[0.019]$ & $0.383(0.034)$ & $0.458[0.019]$ \\
\hline LDIST $^{-}$ & $-0.000[0.009]$ & $-0.005(0.028)$ & $-0.008[1.916]$ \\
\hline LRT_BAHR $_{\mathrm{t}-1}$ & & $0.154(0.058)$ & \\
\hline \multicolumn{4}{|l|}{ Dependent variable: LCE_BAHR } \\
\hline EUDUM & $0.326[0.177]$ & $0.326[0.177]$ & $0.413[0.158]$ \\
\hline GCCDUM & $2.862[0.255]$ & $2.862[0.255]$ & $2.878[0.185]$ \\
\hline NONOPDUM & $-0.894[0.225]$ & $-0.894[0.225]$ & $-0.109[0.262]$ \\
\hline ASIADUM & $0.895[0.222]$ & $0.895[0.222]$ & $1.074[0.191]$ \\
\hline LPOP_TP & $0.650[0.051]$ & $0.650[0.051]$ & $0.688[0.031]$ \\
\hline $\mathrm{N}$ & 556 & 555 & 553 \\
\hline$\overline{\mathrm{R}}_{1}^{2}$ & 0.937 & 0.939 & 0.938 \\
\hline$\overline{\mathrm{R}}_{2}^{2}$ & 0.567 & 0.568 & 0.539 \\
\hline $\mathrm{SER}_{1}$ & 0.427 & 0.423 & 0.428 \\
\hline $\mathrm{SER}_{2}$ & 1.129 & 1.129 & 1.170 \\
\hline Mean of LRT_BAHR & 17.619 & 17.620 & 17.620 \\
\hline Mean of LCE_BAHR & 0.013 & 0.013 & 0.015 \\
\hline
\end{tabular}

GMM Instruments: LPCRI_BAHR t-1 $_{1}$, LPRINC_TP t-1 $_{1}$, LTRADE_BAHR $_{t-1}$, LPOP_TP, LPOP_BAHR, GCCDUM, EUDUM, ASIADUM, NONOPDUM, CONSTANT.

Country effects for each periods obtained from the related fixed effects models.

Standard errors are in brackets and parentheses.

Bold variables are insignificant 
Table 2. KUWAIT

\begin{tabular}{|c|c|c|c|}
\hline \multirow{2}{*}{$\begin{array}{l}\text { 1997-2002: } \\
\text { Dependent variable: LRT_KUW }\end{array}$} & \multicolumn{2}{|c|}{ OLS } & \multirow[t]{2}{*}{ GMM } \\
\hline & (1) & (2) & \\
\hline LCE & $0.999[0.013]$ & $0.703(0.538)$ & $1.006[0.015]$ \\
\hline LPCRI_KUW & $0.986[0.257]$ & $0.752(0.246)$ & $0.932[2.603]$ \\
\hline LPCRI_TP & $-0.061[0.021]$ & $-0.046(0.020)$ & $-0.073[0.022]$ \\
\hline LDIST $^{-}$ & $0.000[0.034]$ & $-0.003(0.033)$ & $0.000[0.036]$ \\
\hline LRT_KUW $\mathrm{t}_{\mathrm{t}-1}$ & & $0.293(0.052)$ & \\
\hline \multicolumn{4}{|l|}{ Dependent variable: LCE_KUW } \\
\hline EUDUM & $2.175[0.214]$ & $2.175[0.214]$ & $2.137[0.182]$ \\
\hline GCCDUM & $2.665[0.314]$ & $2.665[0.314]$ & $2.482[0.178]$ \\
\hline NONOPDUM & $0.076[0.234]$ & $0.076[0.234]$ & $-0.439[0.317]$ \\
\hline ASIADUM & $2.655[0.257]$ & $2.655[0.257]$ & $2.684[0.257]$ \\
\hline LPOP_TP & $0.479[0.057]$ & $0.479[0.057]$ & $0.347[0.174]$ \\
\hline $\mathrm{N}$ & 728 & 722 & 713 \\
\hline$\overline{\mathrm{R}}_{1}^{2}$ & 0.943 & 0.948 & 0.943 \\
\hline$\overline{\mathrm{R}}_{2}^{2}$ & 0.496 & 0.496 & 0.496 \\
\hline $\mathrm{SER}_{1}$ & 0.531 & 0.500 & 0.522 \\
\hline $\mathrm{SER}_{2}$ & 1.553 & 1.553 & 1.552 \\
\hline Mean of LRT_KUW & 17.849 & 17.886 & 17.886 \\
\hline Mean of LCE_KUW & -0.014 & -0.014 & 0.017 \\
\hline 2003-2007: & \multicolumn{2}{|c|}{ OLS } & GMM \\
\hline Dependent variable: LRT_KUW & (1) & (2) & \\
\hline LCE & $1.000[0.013]$ & $0.997(0.052)$ & $0.999[0.014]$ \\
\hline LPCRI_KUW & $1.615[0.153]$ & $1.598(0.174)$ & $1.488[0.147]$ \\
\hline LPCRI_TP & $0.514[0.020]$ & $0.513(0.034)$ & $0.515[0.016]$ \\
\hline LDIST $^{-}$ & $-0.000[0.033]$ & $0.003(0.033)$ & $-0.005[0.042]$ \\
\hline LRT_KUW $_{\mathrm{t}-1}$ & & $0.293(0.052)$ & \\
\hline \multicolumn{4}{|l|}{ Dependent variable: LCE_KUW } \\
\hline EUDUM & $1.028[0.213]$ & $1.028[0.213]$ & $0.655[0.173]$ \\
\hline GCCDUM & $2.152[0.312]$ & $2.152[0.312]$ & $1.788[0.189]$ \\
\hline NONOPDUM & $-0.859[0.285]$ & $-0.859[0.285]$ & $-1.491[0.305]$ \\
\hline ASIADUM & $2.236[0.255]$ & $2.236[0.255]$ & $1.862[0.245]$ \\
\hline LPOP_TP & $0.650[0.051]$ & $0.650[0.051]$ & $0.703[0.043]$ \\
\hline $\mathrm{N}$ & 604 & 603 & 601 \\
\hline$\overline{\mathrm{R}}_{1}^{2}$ & 0.955 & 0.955 & 0.955 \\
\hline$\overline{\mathrm{R}}_{2}^{2}$ & 0.589 & 0.589 & 0.578 \\
\hline $\mathrm{SER}_{1}$ & 0.469 & 0.470 & 0.469 \\
\hline $\mathrm{SER}_{2}$ & 1.410 & 1.411 & 1.434 \\
\hline Mean of LRT_KUW & 18.654 & 18.650 & 18.650 \\
\hline Mean of LCE KUW & 0.021 & 0.021 & 0.018 \\
\hline
\end{tabular}

Country effects for each periods obtained from the related fixed effects models. Standard errors are in brackets and parentheses.

Bold variables are insignificant 
Table 3. OMAN

\begin{tabular}{|c|c|c|c|}
\hline \multirow{2}{*}{$\begin{array}{l}\text { 1997-2002: } \\
\text { Dependent variable: LRT_OMA }\end{array}$} & \multicolumn{2}{|c|}{ OLS } & \multirow[t]{2}{*}{ GMM } \\
\hline & (1) & (2) & \\
\hline $\mathrm{LCE}$ & $1.000[0.011]$ & $0.723(0.051)$ & $1.003[0.012]$ \\
\hline LPCRI OMA & $0.713[0.318]$ & $0.579(0.307)$ & $2.959[0.606]$ \\
\hline LPCRI_TP & $-0.063[0.021]$ & $-0.053(0.020)$ & $-0.071[0.018]$ \\
\hline LDIST $^{-}$ & $-0.000[0.038]$ & $-0.007(0.037)$ & $0.000[0.031]$ \\
\hline LRT_OMA $A_{t-1}$ & & $0.271(0.050)$ & \\
\hline \multicolumn{4}{|l|}{ Dependent variable: LCE_OMA } \\
\hline EUDUM & $2.128[0.231]$ & $2.128[0.231]$ & $2.773[0.203]$ \\
\hline GCCDUM & $3.659[0.334]$ & $3.659[0.334]$ & $3.958[0.210]$ \\
\hline NONOPDUM & $-0.416[0.293]$ & $-0.416[0.293$ & $-0.454[0.313]$ \\
\hline ASIADUM & $3.293[0.280]$ & $3.293[0.280]$ & $4.052[0.257]$ \\
\hline LPOP_TP & $0.405[0.062]$ & $0.405[0.062]$ & $0.376[0.050]$ \\
\hline $\mathrm{N}$ & 684 & 681 & 678 \\
\hline$\overline{\mathrm{R}}_{1}^{2}$ & 0.958 & 0.961 & 0.952 \\
\hline$\overline{\mathrm{R}}_{2}^{2}$ & 0.520 & 0.520 & 0.500 \\
\hline $\mathrm{SER}_{1}$ & 0.487 & 0.467 & 0.522 \\
\hline $\mathrm{SER}_{2}$ & 1.618 & 1.618 & 1.657 \\
\hline Mean of LRT_OMA & 16.979 & 16.992 & 6.992 \\
\hline Mean of LCE_OMA & 0.000 & 0.000 & 0.009 \\
\hline 2003-2007: & \multicolumn{2}{|c|}{ OLS } & GMM \\
\hline Dependent variable: LRT_OMA & (1) & (2) & \\
\hline $\mathrm{LCE}$ & $1.000[0.011]$ & $0.805(0.054)$ & $1.004[0.009]$ \\
\hline LPCRI OMA & $1.468[0.136]$ & $1.273(0.144)$ & $1.327[0.146]$ \\
\hline LPCRI_TP & $0.668[0.017]$ & $0.535(0.400)$ & $0.672[0.015]$ \\
\hline LDIST $^{-}$ & $-0.000[0.033]$ & $-0.003(0.032)$ & $-0.000[0.042]$ \\
\hline LRT $\mathrm{OMA}_{\mathrm{t}-1}$ & & $0.193(0.053)$ & \\
\hline \multicolumn{4}{|l|}{ Dependent variable: LCE_OMA } \\
\hline EUDUM & $0.506[0.181]$ & $0.506[0.181]$ & $0.473[0.144]$ \\
\hline GCCDUM & $3.075[0.262]$ & $3.075[0.262]$ & $3.045[0.255]$ \\
\hline NONOPDUM & $-1.157[0.230]$ & $-1.157[0.230]$ & $-1.228[0.219]$ \\
\hline ASIADUM & $2.314[0.223]$ & $2.314[0.223]$ & $2.508[0.225]$ \\
\hline LPOP_TP & $0.850[0.049]$ & $0.850[0.049]$ & $0.856[0.042]$ \\
\hline $\mathrm{N}$ & 565 & 564 & 562 \\
\hline$\overline{\mathrm{R}}_{1}^{2}$ & 0.969 & 0.971 & 0.968 \\
\hline$\overline{\mathrm{R}}_{2}^{2}$ & 0.724 & 0.723 & 0.717 \\
\hline $\mathrm{SER}_{1}$ & 0.383 & 0.375 & 0.384 \\
\hline $\mathrm{SER}_{2}$ & 1.162 & 1.162 & 1.179 \\
\hline Mean of LRT_OMA & 17.755 & 17.760 & 17.760 \\
\hline Mean of LCE_OMA & -0.012 & -0.012 & -0.003 \\
\hline
\end{tabular}

GMM Instruments: LPCRI OMA ${ }_{t-1}$, LPRINC TP $_{t-1}$, LTRADE OMA $A_{t-1}$, LPOP TP, LPOP OMA, GCCDUM, EUDUM, ASIADUM, NONOPDUM, CONSTANT.

Country effects for each periods obtained from the related fixed effects models. Standard errors are in brackets and parentheses.

Bold variables are insignificant 
Table 4.

\begin{tabular}{|c|c|c|c|}
\hline \multirow{2}{*}{$\begin{array}{l}\text { 1997-2002: } \\
\text { Dependent variable: LRT_QAT }\end{array}$} & \multicolumn{2}{|c|}{ OLS } & \multirow[t]{2}{*}{ GMM } \\
\hline & (1) & (2) & \\
\hline LCE & $1.000[0.014]$ & $0.743(0.045)$ & $0.992[0.016]$ \\
\hline LPCRI QAT & $0.575[0.215]$ & $0.495(0.204)$ & $0.739[0.606]$ \\
\hline LPCRI_TP & $0.570[0.022]$ & $0.411(0.033)$ & $0.548[0.022]$ \\
\hline LDIST $^{-}$ & $-0.000[0.038]$ & $-0.005(0.038)$ & $0.010[0.021]$ \\
\hline LRT_QAT $_{\mathrm{t}-1}$ & & $0.259(0.042)$ & \\
\hline \multicolumn{4}{|l|}{ Dependent variable: LCE QAT } \\
\hline EUDUM & $0.916[0.221]$ & $0.916[0.221]$ & $1.037[0.190]$ \\
\hline GCCDUM & $3.457[0.326]$ & $3.457[0.326]$ & $3.451[0.214]$ \\
\hline NONOPDUM & $-1.072[0.280]$ & $-1.072[0.280]$ & $-0.098[0.332]$ \\
\hline ASIADUM & $2.527[0.259]$ & $2.527[0.259]$ & $2.166[0.239]$ \\
\hline LPOP_TP & $0.727[0.063]$ & $0.727[0.063]$ & $0.807[0.059]$ \\
\hline $\mathrm{N}$ & 719 & 709 & 691 \\
\hline$\overline{\mathrm{R}}_{1}^{2}$ & 0.938 & 0.947 & 0.941 \\
\hline$\overline{\mathrm{R}}_{2}^{2}$ & 0.541 & 0.541 & 0.512 \\
\hline $\operatorname{SER}_{1}$ & 0.612 & 0.568 & 0.601 \\
\hline $\mathrm{SER}_{2}$ & 1.597 & 1.597 & 1.617 \\
\hline Mean of LRT_QAT & 16.773 & 16.791 & 16.991 \\
\hline Mean of LCE_QAT & -0.043 & -0.043 & -0.003 \\
\hline 2003-2007: & \multicolumn{2}{|c|}{ OLS } & GMM \\
\hline Dependent variable: LRT_QAT & (1) & (2) & \\
\hline LCE & $0.999[0.013]$ & $0.910(0.054)$ & $1.002[0.012]$ \\
\hline LPCRI QAT & $1.452[0.099]$ & $1.317(0.127)$ & $1.532[0.099]$ \\
\hline LPCRI_TP & $0.567[0.019]$ & $0.516(0.036)$ & $0.572[0.018]$ \\
\hline LDIST $^{-}$ & $0.000[0.031]$ & $0.001(0.031)$ & $-0.001[0.022]$ \\
\hline LRT_QAT $_{\mathrm{t}-1}$ & & $0.086(0.051)$ & \\
\hline \multicolumn{4}{|l|}{ Dependent variable: LCE_QAT } \\
\hline EUDUM & $0.858[0.186]$ & $0.858[0.186]$ & $0.962[0.158]$ \\
\hline GCCDUM & $2.957[0.273]$ & $2.957[0.273]$ & $3.119[0.172]$ \\
\hline NONOPDUM & $-0.776[0.235]$ & $-0.776[0.235]$ & $-0.617[0.228]$ \\
\hline ASIADUM & $2.133[0.217]$ & $2.133[0.217]$ & $1.662[0.255]$ \\
\hline LPOP_TP & $0.753[0.052]$ & $0.753[0.052]$ & $0.881[0.049]$ \\
\hline $\mathrm{N}$ & 609 & 609 & 609 \\
\hline$\overline{\mathrm{R}}_{1}^{2}$ & 0.950 & 0.951 & 0.951 \\
\hline$\overline{\mathrm{R}}_{2}^{2}$ & 0.635 & 0.635 & 0.621 \\
\hline $\mathrm{SER}_{1}$ & 0.474 & 0.472 & 0.475 \\
\hline $\mathrm{SER}_{2}$ & 1.229 & 1.229 & 1.254 \\
\hline Mean of LRT_QAT & 18.020 & 18.020 & 18.020 \\
\hline Mean of LCE_QAT & 0.003 & 0.002 & 0.003 \\
\hline
\end{tabular}

GMM Instruments: LPCRI QAT ${ }_{t-1}$, LPRINC TP $_{t-1}$, LTRADE QAT $_{t-1}$, LPOP TP, LPOP QAT, GCCDUM, EUDUM, ASIADUM, NONOPDUM, CONSTANT.

Country effects for each periods obtained from the related fixed effects models.

Standard errors are in brackets and parentheses.

Bold variables are insignificant 
Table 5. SAUDI ARABIA

\begin{tabular}{|c|c|c|c|}
\hline \multirow{2}{*}{$\begin{array}{l}\text { 1997-2002: } \\
\text { Dependent variable: LRT_SAU }\end{array}$} & \multicolumn{2}{|c|}{ OLS } & \multirow[t]{2}{*}{ GMM } \\
\hline & (1) & (2) & \\
\hline LCE & $1.000[0.009]$ & $0.846(0.054)$ & $0.997[0.012]$ \\
\hline LPCRI_SAU & $1.284[0.284]$ & $1.417(0.291)$ & $-3.179[3.318]$ \\
\hline LPCRI_TP & $0.091[0.011]$ & $0.075(0.013)$ & $0.091[0.014]$ \\
\hline LDIST $^{-}$ & $0.000[0.021]$ & $-0.002(0.022)$ & $-0.014[0.043]$ \\
\hline LRT_SAU $_{\mathrm{t}-1}$ & & $0.152(0.052)$ & \\
\hline \multicolumn{4}{|l|}{ Dependent variable: LCE_SAU } \\
\hline EUDUM & $1.889[0.176]$ & $1.889[0.176]$ & $1.617[0.129]$ \\
\hline GCCDUM & $1.836[0.273]$ & $1.836[0.273]$ & $1.465[0.198]$ \\
\hline NONOPDUM & $0.262[0.225]$ & $0.262[0.225]$ & $-0.677[0.232]$ \\
\hline ASIADUM & $1.924[0.198]$ & $1.924[0.198]$ & $1.450[0.184]$ \\
\hline LPOP_TP & $0.482[0.051]$ & $0.482[0.051]$ & $0.430[0.043]$ \\
\hline $\mathrm{N}$ & 770 & 761 & 745 \\
\hline$\overline{\mathrm{R}}_{1}^{2}$ & 0.969 & 0.969 & 0.947 \\
\hline$\overline{\mathrm{R}}_{2}^{2}$ & 0.466 & 0.466 & 0.436 \\
\hline $\mathrm{SER}_{1}$ & 0.319 & 0.319 & 0.413 \\
\hline $\mathrm{SER}_{2}$ & 1.315 & 1.315 & 1.296 \\
\hline Mean of LRT_SAU & 19.755 & 19.773 & 19.773 \\
\hline Mean of LCE_SAU & -0.050 & -0.050 & 0.019 \\
\hline 2003-2007: & \multicolumn{2}{|c|}{ OLS } & GMM \\
\hline Dependent variable: LRT_SAU & (1) & (2) & \\
\hline LCE & $1.000[0.007]$ & $0.961(0.049)$ & $1.008[0.010]$ \\
\hline LPCRI_SAU & $1.532[0.106]$ & $1.479(0.132)$ & $1.588[0.113]$ \\
\hline LPCRI-TP & $0.433[0.010]$ & $0.416(0.024)$ & $0.433[0.010]$ \\
\hline LDIST $^{-}$ & $-0.000[0.018]$ & $-0.003(0.018)$ & $-0.001[0.030]$ \\
\hline LRT_SAU $_{\mathrm{t}-1}$ & & $0.039(0.049)$ & \\
\hline \multicolumn{4}{|l|}{ Dependent variable: LCE_SAU } \\
\hline EUDUM & $1.004[0.199]$ & $1.004[0.199]$ & $0.503[0.147]$ \\
\hline GCCDUM & $2.041[0.303]$ & $2.041[0.303]$ & $1.653[0.256]$ \\
\hline NONOPDUM & $-0.371[0.252]$ & $-0.371[0.252]$ & $-1.171[0.210]$ \\
\hline ASIADUM & $1.606[0.221]$ & $1.606[0.221]$ & $1.081[0.195]$ \\
\hline LPOP_TP & $0.717[0.056]$ & $0.717[0.056]$ & $0.696[0.049]$ \\
\hline $\mathrm{N}$ & 645 & 644 & 642 \\
\hline$\overline{\mathrm{R}}_{1}^{2}$ & 0.981 & 0.981 & 0.981 \\
\hline$\overline{\mathrm{R}}_{2}^{2}$ & 0.504 & 0.504 & 0.471 \\
\hline $\mathrm{SER}_{1}$ & 0.267 & 0.267 & 0.268 \\
\hline $\mathrm{SER}_{2}$ & 1.351 & 1.351 & 1.399 \\
\hline Mean of LRT_SAU & 20.358 & 20.360 & 20.360 \\
\hline Mean of LCE_SAU & -0.007 & -0.007 & -0.005 \\
\hline
\end{tabular}

GMM Instruments: LPCRI_SAU ${ }_{t-1}, L_{\text {LPINC_TP }}$ t-1, LTRADE_SAU $t_{t-1}$, LPOP_TP, LPOP_SAU, GCCDUM, EUDUM, ASIADUM, NONOPDUM, CONSTANT.

Country effects for each periods obtained from the related fixed effects models.

Standard errors are in brackets and parentheses.

Bold variables are insignificant 
Table 6. UNITED ARAB EMIRATES

\begin{tabular}{|c|c|c|c|}
\hline \multirow{2}{*}{$\begin{array}{l}\text { 1997-2002: } \\
\text { Dependent variable: LRT_UAE }\end{array}$} & \multicolumn{2}{|c|}{ OLS } & \multirow[t]{2}{*}{ GMM } \\
\hline & (1) & (2) & \\
\hline LCE & $1.000[0.008]$ & $0.794(0.044)$ & $1.006[0.014]$ \\
\hline LPCRI_UAE & $0.941[0.170]$ & $0.888(0.168)$ & $4.473[0.659]$ \\
\hline LPCRI_TP & $-0.226[0.011]$ & $-0.185(0.015)$ & $-0.229[0.016]$ \\
\hline LDIST $^{-}$ & $-0.000[0.021]$ & $-0.001(0.020)$ & $-0.016[0.021]$ \\
\hline LRT_UAE $_{t-1}$ & & $0.205(0.043)$ & \\
\hline \multicolumn{4}{|l|}{ Dependent variable: LCE_UAE } \\
\hline EUDUM & 2.214 [0.192] & $2.214[0.192]$ & $2.377[0.163]$ \\
\hline GCCDUM & $3.195[0.293]$ & $3.195[0.293]$ & $3.009[0.144]$ \\
\hline NONOPDUM & $1.308[0.227]$ & $1.308[0.227]$ & $1.214[0.233]$ \\
\hline ASIADUM & $2.367[0.228]$ & $2.367[0.228]$ & $2.604[0.272]$ \\
\hline LPOP_TP & $0.319[0.050]$ & $0.319[0.050]$ & $0.213[0.043]$ \\
\hline $\mathrm{N}$ & 798 & 790 & 779 \\
\hline$\overline{\mathrm{R}}_{1}^{2}$ & 0.972 & 0.974 & 0.943 \\
\hline$\overline{\mathrm{R}}_{2}^{2}$ & 0.477 & 0.477 & 0.463 \\
\hline SER $_{1}$ & 0.319 & 0.310 & 0.461 \\
\hline $\mathrm{SER}_{2}$ & 1.429 & 1.429 & 1.454 \\
\hline Mean of LRT_UAE & 19.240 & 19.249 & 19.249 \\
\hline Mean of LCE_UAE & -0.007 & -0.007 & 0.008 \\
\hline 2003-2007: & \multicolumn{2}{|c|}{ OLS } & GMM \\
\hline Dependent variable: LRT_UAE & (1) & (2) & \\
\hline LCE & $0.999[0.010]$ & $0.752(0.056)$ & $0.995[0.014]$ \\
\hline LPCRI_UAE & $2.005[0.117]$ & $1.468(0.167)$ & $1.863[0.119]$ \\
\hline LPCRI_TP & $0.122[0.012]$ & $0.091(0.014)$ & $0.125[0.011]$ \\
\hline LDIST $^{-}$ & $0.000[0.023]$ & $-0.000(0.022)$ & $0.056[0.066]$ \\
\hline LRT_UAE $_{t-1}$ & & $0.244(0.054)$ & \\
\hline \multicolumn{4}{|l|}{ Dependent variable: LCE_UAE } \\
\hline EUDUM & $1.216[0.184]$ & $1.216[0.184]$ & $1.345[0.148]$ \\
\hline GCCDUM & $2.779[0.284]$ & $2.779[0.284]$ & $2.629[0.140]$ \\
\hline NONOPDUM & $0.436[0.216]$ & $0.436[0.216]$ & $0.373[0.242]$ \\
\hline ASIADUM & $1.710[0.218]$ & $1.710[0.218]$ & $2.213[0.245]$ \\
\hline LPOP_TP & $0.506[0.048]$ & $0.506[0.048]$ & $0.431[0.041]$ \\
\hline $\mathrm{N}$ & 664 & 663 & 661 \\
\hline$\overline{\mathrm{R}}_{1}^{2}$ & 0.969 & 0.971 & 0.968 \\
\hline$\overline{\mathrm{R}}_{2}^{2}$ & 0.494 & 0.494 & 0.479 \\
\hline $\mathrm{SER}_{1}$ & 0.322 & 0.314 & 0.326 \\
\hline $\mathrm{SER}_{2}$ & 1.253 & 1.253 & 1.276 \\
\hline Mean of LRT_UAE & 20.134 & 20.136 & 20.136 \\
\hline Mean of LCE UAE & 0.002 & 0.002 & 0.006 \\
\hline
\end{tabular}

GMM Instruments: LPCRI_UAE $\mathrm{t}_{\mathrm{t}-1}, \mathrm{LPRINC}_{-} \mathrm{TP}_{\mathrm{t}-1}, \mathrm{LTRADE}_{-} \mathrm{LAE}_{\mathrm{t}-1}$, LPOP_TP, LPOP_UAE, GCCDUM, EUDUM, ASIADUM, NONOPDUM, CONSTANT.

Country effects for each periods obtained from the related fixed effects models. Standard errors are in brackets and parentheses.

Bold variables are insignificant 
Table D1. Trade Equation-Residuals Panel Unit Root Tests

\begin{tabular}{|c|c|c|c|c|c|}
\hline \multirow{2}{*}{\multicolumn{2}{|c|}{$\begin{array}{l}\text { IPS W-test: } \\
\mathrm{H}_{0} \text { : } \\
\text { individual unit root process }\end{array}$}} & \multirow{2}{*}{\multicolumn{2}{|c|}{$\begin{array}{c}\text { Individual Effects \& } \\
\text { Individual Linear Trends }\end{array}$}} & \multirow{2}{*}{\multicolumn{2}{|c|}{$\begin{array}{c}\text { Individual Effects \& } \\
\text { Individual Linear Trends }\end{array}$}} \\
\hline & & & & & \\
\hline COUNTRY & Specification & 1997-2002 & 2003-2007 & 1997-2002 & 2003-2007 \\
\hline \multirow{2}{*}{ Bahrain } & & 0.262 ( & & \multirow{2}{*}{$0.221(0.587)$} & \multirow{2}{*}{$-1.912(0.028)$} \\
\hline & Dy & 0.401( & -1.6 & & \\
\hline \multirow{2}{*}{ Kuwait } & Stati & $-0.150(0.440)$ & $-8.461(0.00)$ & \multirow{2}{*}{$0.142(0.556)$} & \multirow{2}{*}{$-6.656(0.00)$} \\
\hline & & -0.597 & $-8.125(0.00)$ & & \\
\hline \multirow{2}{*}{ Oman } & & $-0.975(0.165)$ & $-13.741(0.0$ & \multirow{2}{*}{$-0.762(0.223)$} & \multirow{2}{*}{$-7.208(0.00)$} \\
\hline & Dynan & $-1.332(0.091)$ & $-3.430(0.0$ & & \\
\hline \multirow{2}{*}{ Qatar } & Static & $0.908(0.818)$ & $-4.812(0.00)$ & \multirow{2}{*}{$1.244(0.893)$} & \multirow{2}{*}{$-4.949(0.00)$} \\
\hline & & $-1.906(0.028)$ & $-14.558(0.00)$ & & \\
\hline \multirow{2}{*}{ Saudi Arabia } & Static & $0.606(0.728)$ & $-29.884(0.00)$ & \multirow{2}{*}{$-0.220(0.413)$} & \multirow{2}{*}{$-0.560(0.288)$} \\
\hline & Dynamic & $-0.163(0.435)$ & $-4.547(0.00)$ & & \\
\hline \multirow{2}{*}{ UAE } & Static & $0.092(0.537)$ & $-1.893(0.029)$ & \multirow{2}{*}{$-0.024(0.490)$} & \multirow{2}{*}{$-1.440(0.075)$} \\
\hline & Dynamic & $-0.146(0.442)$ & $-4.387(0.00)$ & & \\
\hline
\end{tabular}

The test statistics in the first rows of the OLS and the GMM columns are for the static system equations, whereas in the second rows of the OLS columns are for the dynamic system equations.

Probability values are in parentheses.

Bold values show the acceptance of the unit root processes at the 5 and $10 \%$ significance levels.

Table D2. Trade Equation-Residuals Panel Unit Root Tests

\begin{tabular}{|c|c|c|c|c|c|}
\hline \multirow{2}{*}{\multicolumn{2}{|c|}{$\begin{array}{l}\text { LLC t-test: } \\
\mathrm{H}_{0} \text { : } \\
\text { common unit root process }\end{array}$}} & \multirow{2}{*}{\multicolumn{2}{|c|}{$\begin{array}{c}\text { Individual Effects \& } \\
\text { Individual Linear Trends }\end{array}$}} & \multirow{2}{*}{\multicolumn{2}{|c|}{$\begin{array}{c}\text { Individual Effects \& } \\
\text { Individual Linear Trends } \\
\text { GMM }\end{array}$}} \\
\hline & & & & & \\
\hline COUNTRY & Specification & $1997-2002$ & 2003-2007 & 1997-2002 & 2003-2007 \\
\hline Bahrain & $\begin{array}{c}\text { Static } \\
\text { Dynamic }\end{array}$ & $\begin{array}{l}-17.73(0.00) \\
-15.05(0.00)\end{array}$ & $\begin{array}{l}-16.14(0.00) \\
-38.94(0.00)\end{array}$ & $-16.59(0.00)$ & $-15.97(0.00)$ \\
\hline Kuwait & $\begin{array}{c}\text { Static } \\
\text { Dynamic }\end{array}$ & $\begin{array}{l}-28.13(0.00) \\
-37.19(0.00)\end{array}$ & $\begin{array}{l}-46.19(0.00) \\
-51.68(0.00)\end{array}$ & $-23.89(0.00)$ & $-47.89(0.00)$ \\
\hline Oman & $\begin{array}{c}\text { Static } \\
\text { Dynamic }\end{array}$ & $\begin{array}{l}-34.05(0.00) \\
-41.50(0.00)\end{array}$ & $\begin{array}{l}-349.8(0.00) \\
-72.93(0.00)\end{array}$ & $-32.76(0.00)$ & $-170.5(0.00)$ \\
\hline Qatar & $\begin{array}{c}\text { Static } \\
\text { Dynamic }\end{array}$ & $\begin{array}{l}-18.82(0.00) \\
-39.49(0.00)\end{array}$ & $\begin{array}{l}-61.27(0.00) \\
-104.8(0.00)\end{array}$ & $-15.49(0.00)$ & $-68.44(0.00)$ \\
\hline Saudi Arabia & $\begin{array}{c}\text { Static } \\
\text { Dynamic }\end{array}$ & $\begin{array}{l}-21.45(0.00) \\
-29.36(0.00)\end{array}$ & $\begin{array}{l}-60.66(0.00) \\
-33.57(0.00)\end{array}$ & $-26.01(0.00)$ & $-1.278(0.10)$ \\
\hline UAE & $\begin{array}{c}\text { Static } \\
\text { Dynamic }\end{array}$ & $\begin{array}{l}-14.37(0.00) \\
-23.70(0.00)\end{array}$ & $\begin{array}{l}-30.67(0.00) \\
-32.75(0.00)\end{array}$ & $-24.83(0.00)$ & $-33.18(0.00)$ \\
\hline
\end{tabular}

The test statistics in the first rows of the OLS and the GMM columns are for the static system equations, whereas in the second rows of the OLS columns are for the dynamic system equations.

Probability values are in parentheses.

Bold values show the acceptance of the unit root processes at the 5 and $10 \%$ significance levels. 